\title{
The Analysis of Packaging Design Product Organic Food Eco Spirit Center
}

\author{
Ratnasari Wijaya ${ }^{1}$ Kurnia Setiawan $^{1 *}$ Herlina Kartaatmadja $^{1}$
}

\author{
${ }^{1}$ Design Communication Visual, Faculty of Art and Design, Tarumanagara University, Jakarta, Indonesia \\ *Corresponding author. Email: kurnias@fsrd.untar.ac.id
}

\begin{abstract}
With high competition in the food and beverage industries, entrepreneurs give efforts to improve the quality of their packaging to satisfy and build good relationships with consumers through packaging design (packaging). A product must be different from the competitors, such as is through packaging design. The Eco Spirit Center organic food business has a weakness. It does not have a good packaging design. This research examined the packaging design process for the Eco Spirit Center. This research was qualitative research. The object of research was packaging design, conducted in Ciawi, West Java in July - December 2020. This research used design methodology. The data collection methods used were literature study and interviews. Packaging designs made for food; Sorghum Brownies (Brownies Sorgum), Layers of Pumpkin(Lapis Waluh), and Perfect Cassava(Singkong Mempur), for drinks were; Seruni (lemon lime/Sereh Jeruk Nipis) and Jagoramon (red ginger, lemon palm sugar/Jahe Merah Gula Aren Lemon). The packaging design had the theme of natural harmony (ecology) by processing illustrations, colors, typography, and media. Through good packaging design, it is expected that it can make each packaging easier and attract consumers.
\end{abstract}

Keywords: Design, packaging, organic food

\section{INTRODUCTION}

Packaging design or it can be called packaging is one of factors that has to be considered in three elements such as Positioning, Differentiation, Brand on a product. Consumers can be stimulated by their attention by the visual attractiveness seen in their products by utilizing colors, shapes, illustrations, and of course the brand, a packaging serves as a means of packaging, shaping an image, protecting, storing, identifying and differentiating a product in the market. Because a package will first describe and image a product [1].

Along with the industrial development that has entered the fourth generation, the industry competition is getting higher. Industrial development is largely influenced by the millennial generation. In their daily lives, they can't be separated from existence and technology. Almost all entrepreneurs target millennials as potential target markets, including the food and beverage industry. Moreover, the millennial market is starting to improve the quality of their packaging.

The key to win the competition is providing value to consumers through delivering innovative and quality products at competitive prices. To satisfy and build good relationships with consumers, a product must be different from the competitors. One of the ways is through packaging design or it can be called packaging. However, until now, many entrepreneurs have not paid much attention to the packaging of their products especially for home-based business products, both food or beverage products. They even package their products simply [2].

One of the important factors in influencing consumer intention is the popularity including branding and packaging. Consumers can be stimulated by their attention by the visual appeal seen in their products by utilizing their colors, shapes, illustrations and brands. The attractiveness of a product can't be separated from the packaging because packaging is a very important object for the continuity of a product.

Packaging is a factor that creates a certain image that the product wants to build. The design of a package deals with everything such as shape, structure, material, color, image, and design elements with product information so that the product can be marketed [3].

Marianne Rosner (2007: 33) concludes "Packaging design is a creative business that relates shapes, structures, materials, colors, images, typography, and design elements with product information so that products can be marketed. Packaging design applies to wrapping, protecting, shipping, releasing, storing, identifying and differentiating a product in the market" [4]. 


\section{BACKGROUND}

As the organic product, The food made by the Eco Spirit Center consists of food and beverages processed using organic ingredients or of natural origin, without chemicals and preservatives because they use garden products. The way to market this product through word of mouth, and buy it on the spot. The increasingly competitive market competition for food and beverage products is a big opportunity and challenge for Eco Spirit organic food businesses to improve their services so that they are able to compete with other competitors.

According to the explanation above, the Eco Spirit Center organic food business has weaknesses in the packaging aspect. The product has no identity, does not have packaging or packaging. Thus, it does not have an appeal for consumers and it complicates customers if they want to buy to take home without packaging. Meanwhile, on the other hand, there are many similar products that compete in the online food product market with attractive packaging.

It is expected that the design of organic food packaging can provide product identity, facilitate packaging and attract consumer interest. [5]

\section{METHODS}

\subsection{Methodology of Visual Communication Design}

(A) Target Audiences, (B) Key Facts, (C) Creative Strategies and Concepts, (D) Creative Decisions, (E) Media

\subsubsection{Method of collecting the data}

Methods used by researcher in this design were qualitative research methods in an effort to find information, analyzing data and solving problems [6], they are explained below:

a) Literature review

Collecting the data for this packaging design used observation toward books that related and provided information about promotional design, promotional media, and packaging design. Literature study was also conducted by searching data from the internet.

b) Interview

Interview is a direct communication between researcher and respondents. Communication takes place in the form of questions and answers in face-toface relationships. Therefore, in conducting interviews, data collectors have prepared research instruments in the form of alternative written questions. Data collection was carried out through interviews with respondents by providing input, suggestions and information related to packaging design.

\subsubsection{Method of data analysis}

Method of Data Analysis used was SWOT analysis to analyze product features. SWOT analysis is an acronym for Strengths, Weaknesses, Opportunities, and Threats. SWOT analysis was used to assess the strengths and weaknesses of the resources owned as well as external opportunities and challenges faced including competitors [7].

The following is a description of a SWOT analysis based on internal and external factors of Eco Spirit Center products:

Strength

- $\quad$ Not using preservatives.

- Utilizing garden/natural products

- Healthy

- No chemicals

Weakness

- There had been no packaging

- It did not interest customers

Opportunity

- There are no permanent competitors

- There is an online delivery to ease customer in ordering

- Low prices can be an opportunity

- $\quad$ Fresh food products

- The materials used are natural origin

- No chemicals and preservatives

Threat

- It is not easy to recognize because there is no definite packaging and identity

- Consumers are certain people

\section{FINDINGS AND DISCUSSIONS}

\subsection{Target Audience}

1. Geographic : Ciawi, Bogor, West Java

2. Demographic

Age

Life Stage : Adult

Gender : Man and Woman

SES : Middle

3. Psychographics :

Culinary enthusiasts

Cake /snack lover

4. Behavioral

Love new things

Implement a healthy life 


\subsection{Key Facts}

The facts were found based on analysis that had been concluded. They play important role in packaging decision:

a. Packaging highly affects the marketing process

b. The design on the packaging has a considerable effect on the product

c. The appearance of the packaging can affect product quality

\subsection{The Concept and Creative Strategy}

\subsubsection{Creative strategy}

In designing, the creative strategy used by the researcher was packaging design using efficient materials, thus it would be easy to carry and safe. In addition, the application of color and typography was conditioned in packaging design. This packaging design featured a packaging design that can attract consumers and also give an impression to consumers.

\subsubsection{Creative concept}

1. Main theme of packaging

The design theme of this packaging design is nature harmony (ecological).

2. Idea

The big idea of this design is to design food product packaging that aims to attract consumer interest and also give an impression which is then translated into several visual elements on the packaging such as illustrations, colors, typography, and the materials used.

\subsubsection{Creative decision}

\subsubsection{Verbal decision}

\section{a. Type of food}

1. Brownies sorghum

Sorghum is a versatile plant that can be used as a source of food, animal feed and industrial raw materials. Besides, sorghum is known to have better benefits than wheat flour because it is gluten free.

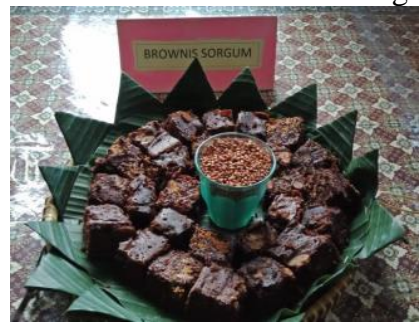

Figure 1 Brownies sorghum
(Source: Documentation of ecospirit center)

\section{Lapis waluh}

Waluh (Cucurbita) includes a group of vines belonging to the Pumpkin (Cucurbitaceae) tribe that produces large consumption fruit with the same name.

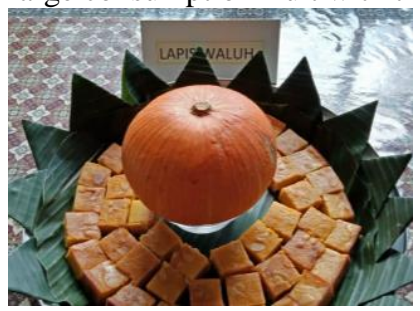

Figure 2 Lapis waluh

(Source: Documentation of ecospirit center)

3. Singkong mempur / soft cassava

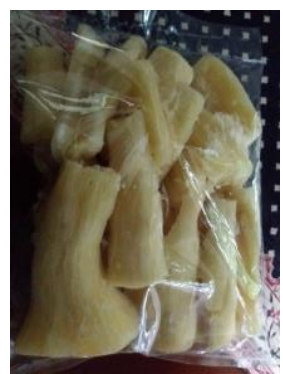

Figure 3 Singkong mempur

(Source: Documentation of ecospirit center)

b. Type of beverage

1. Seruni (Sereh Jeruk Nipis/Lemongrass Lime)

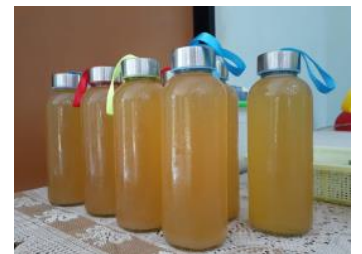

Figure 4 Seruni

(Source: Documentation of ecospirit center)

2. Jagoramon (jahe merah gula aren lemon / red ginger palm sugar lemon)

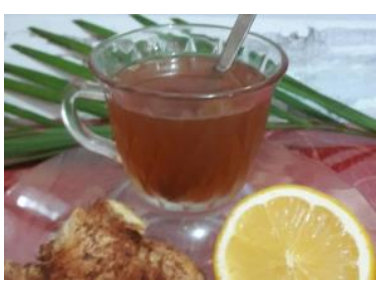

Figure 5 Jagoramon

(Source: Google.com) 


\subsubsection{Visual decision}

a. Illustration

The illustration that would be used in this packaging design features an illustration in the form of a simple shape or pattern of leaves. With a simple appearance of the leaf shape, it will create a natural impression. Besides, it is also inspired by the leaf pattern of the handkerchief tree (pohon sapu tangan) that is one of the famous trees in the Eco Spirit Center.

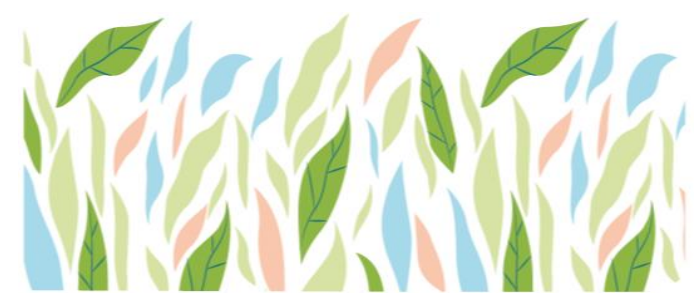

Figure 6 Packaging design (Source: Personal document)

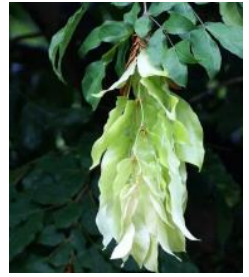

Figure 7 Pohon saputangan (source: Google.com)

b. Color

Coloring in the packaging design used colors that reflect the natural atmosphere, such as green. Each food had a different color as the identity of each product, thus the target market is easy to recognize. These colors are:

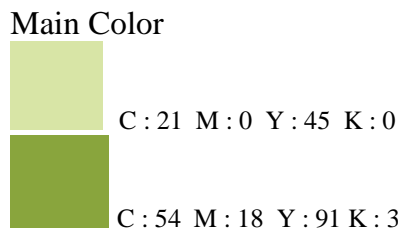

Color in the form of leaves

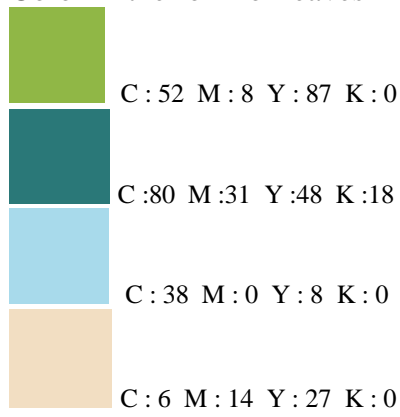

Color in Food Label
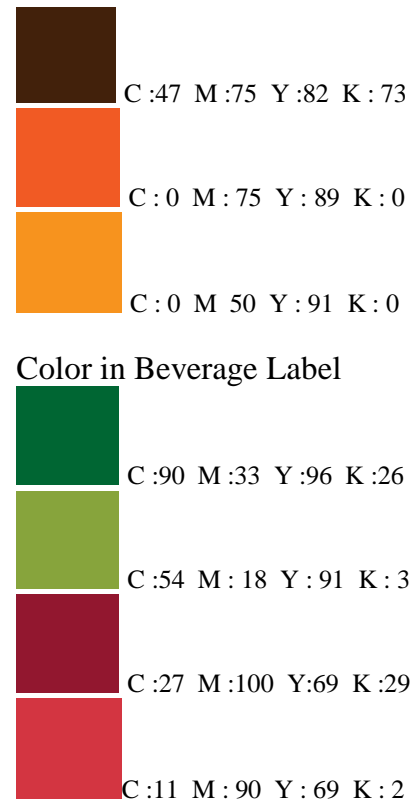

c. Typography

The type of font used was the Constance font, the type of font used in the Eco Spirit Center logo. Besides simple, it can become an identity and also a characteristic of Eco Spirit Center food products, so that when customers see food labels, they have already known that this is food produced by Eco Spirit Center.

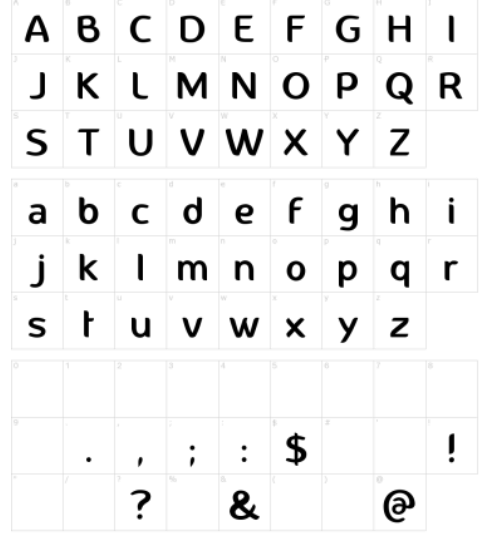

Figure 8 Font constance (source: Google.com)

\subsubsection{Physical decision}

1) Physical decisions of food packaging

- Material : 300 gsm Kraft Paper, Laminate in (resistant to water and oil)

- Size : $31,5 \times 11 \times 5,5 \mathrm{~cm}$

- Shape : Rectangle 
2) Physical Decisions of Beverage Packaging

- Material : Glass Bottle

- $\quad$ Size

$: 21 \times 4,5 \mathrm{~cm}$

- Shape

: Cylinder

- $\quad$ Capacity : $600 \mathrm{ml}$

3) Physical Decisions of Beverage Label

- Material : Vinyl Sticker

- $\quad$ Size

: $21,5 \times 10,5 \mathrm{~cm}$

\subsubsection{Design media}

1) Visual pattern of food packaging

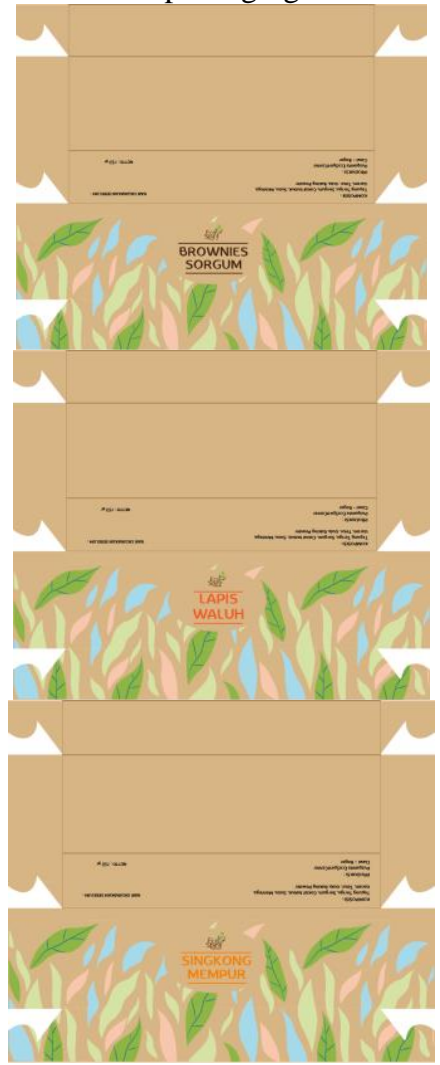

Figure 9 Visualization pattern (Source: Personal document)

2) Design of food packaging

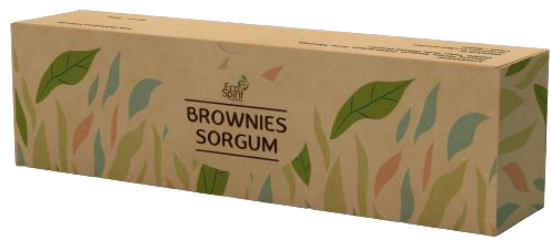

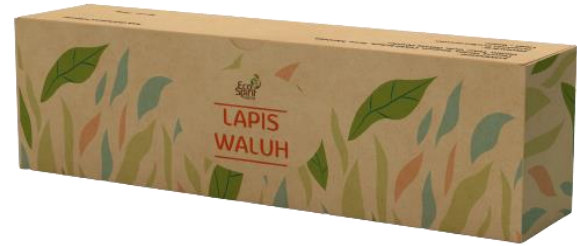

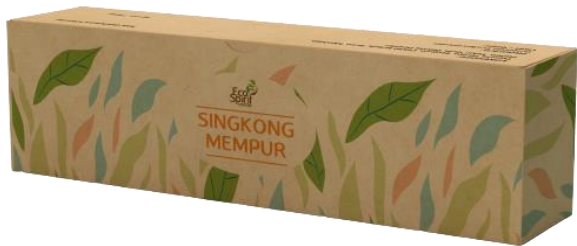

Figure 10 Front view (Source: Personal document)
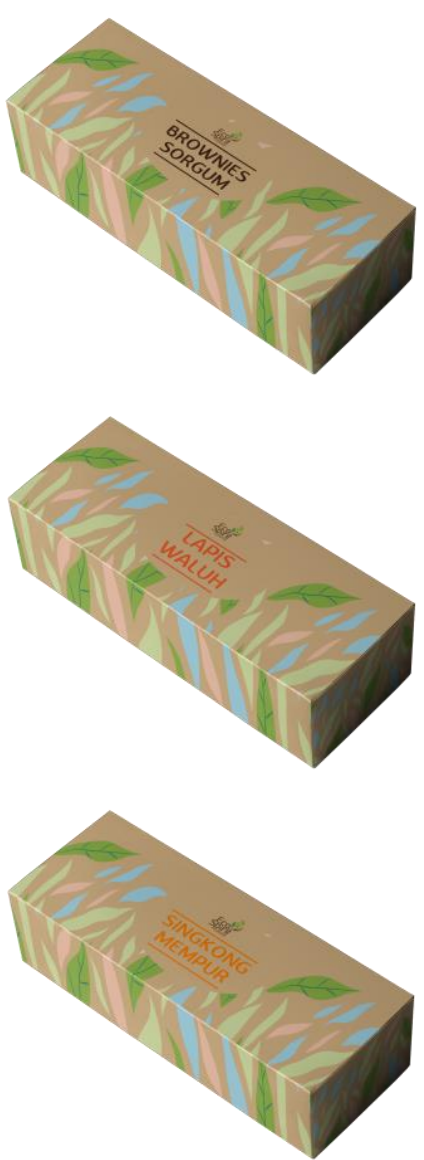

Figure 11 Top view (Source: Personal document) 
3) Design of food label

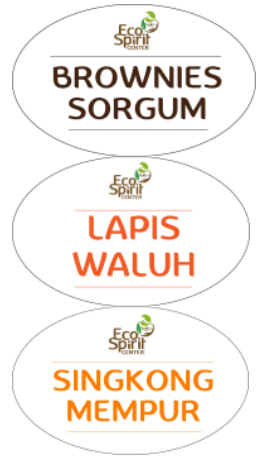

Figure 12 Food label (Source: Personal document)

4) Design on beverage packaging
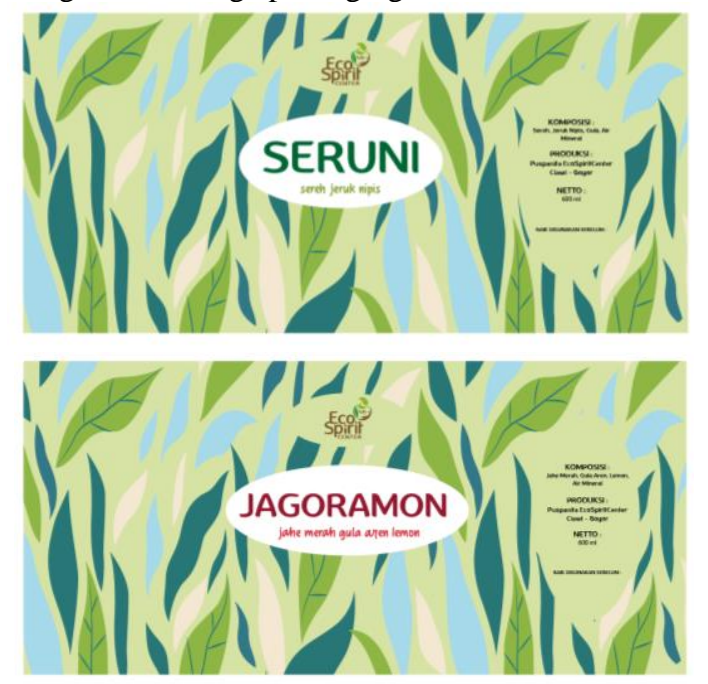

Figure 13 Beverage label

(Source: Personal document)

4) Desain kemasan minuman

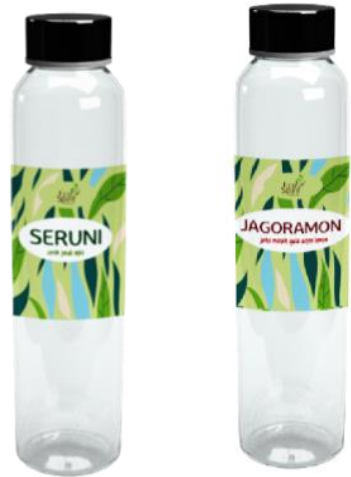

Figure 14 Bottle packaging (Source: Personal document)

\subsubsection{Supporting media}

1) Paper Bag

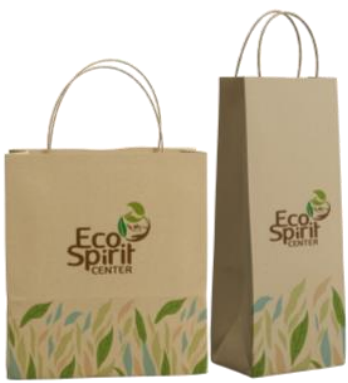

Figure 15 Paper Bag (source: Personal Document)

2) Bottle Pouch

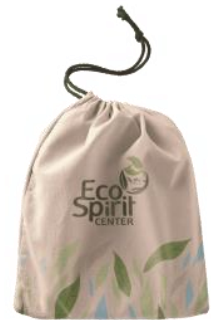

Figure 16 Pouch

(Source: Personal document)

3) Bottle Tag

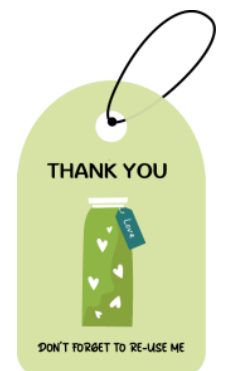

Figure 17 Bottle tag

(Source: Personal document)

4) Flyer

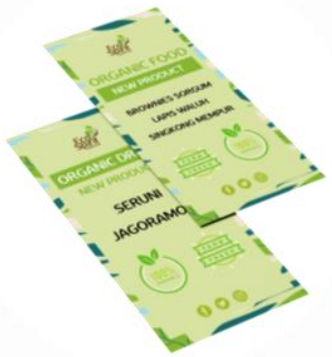

Figure 18 Flyer

(Source: Personal document) 
5) X-Banner

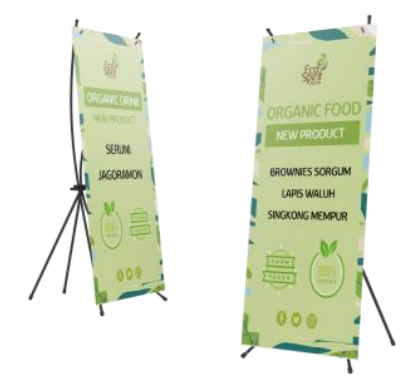

Figure 19 X-banner

(Source: Personal documentation)

\section{CONCLUSIONS}

The Design process uses the design methodology of the Visual Communication Design Final Project guidelines; (A) Target Audiences, (B) Key Facts, (C) Creative Strategy and Concept (D) Creative Decisions, (E) Media. The design theme of food and beverage packaging designs from the Eco Spirit Center are natural and ecological harmony. Product packaging design is manifested into several visual elements on the packaging such as (1) illustrations, (2) colors, (3) typography, and (4) materials used. The illustration used shows a simple shape or pattern of the leaves of the handkerchief tree (pohon sapu tangan) which is a famous/typical tree at the Eco Spirit Center. Coloring uses colors that reflect the natural atmosphere, namely green. The type of font used is the Constance font, the type of font used in the Eco Spirit Center logo itself so that it fits into the identity and becomes the hallmark of Eco Spirit Center food products. The materials used are cardboard and glass bottles so they are environmentally friendly.

\section{ACKNOWLEDGMENT}

Researcher is supported by Sr. Marissa as a model client and informant who has given researchers the opportunity to make this packaging design. Besides, she has also provided information about the product designed and also to the Tarumanagara University Research and Community Service Institute (LPPM). Not to forget, I also give gratitude to the Eco Spirit Center for entrusting me to create this design.

\section{REFERENCES}

[1] H. Tunky, C. Kohardinata, 2016. Perancangan Desain Kemasan Pada Merk Keripik Pisang Bananation Di Surabaya. PERFORMA: Jurnal Manajemen dan Start-Up Bisnis 1(5), 576 - 583.

[2] W. Sholikatin, 2019. Perancangan Kemasan Produk Keripik Makaroni Spiral Makeci. DESKOVI: Art and Design Journal, 2(2), 73-80.

[3] M. R. Klimchuk, dan S. A. Krasovec. 2006. Desain Kemasan. Jakarta: Erlangga.

[4] M. R. Klimchuk, dan S. A. Krasovec. 2007. Desain Kemasan, Jakarta: Erlangga.

[5] W. D. Z. Ananto, dan S.P. A. Rezza 2014. Persepsi Konsumen terhadap Makanan Organik di Yogyakarta. PELITA, 9(1), 36-48.

[6] J. W Creswell, 2014. RESEARCH DESIGN, Qualitative, Quantitative, and Mixed Methods Approaches atau RESEARCH DESIGN: Pendekatan Metode Kualitatif, Kuantitatif, dan Campuran, Terjemahan Achmad Fawaid \& Rianayati Kusmini P. 2016. Yogyakarta: Pustaka Pelajar.

[7] J. Hartono, 2005. Sistem Informasi Strategi Untuk Keunggulan Kompetitif. Yogyakarta: Andi Offset. 